\title{
Littoral States Maritme Security: Issues and Challenges
}

\author{
Devakumar.j.
}

\begin{abstract}
"... a nation's social and economic well-being is intricately linked to the seas, not only for trade but also how it faces threats to its own security that develop across the seas...our resolve to achieve high growth can be realised only if our maritime frontiers and assets are safe, stable and act as enablers. The Indian Navy, as the primary element of India's maritime power, has the challenging task of safeguarding the country's maritime interests. ".....Shri -Pranab Mukherjee, Hon'ble President of India

(Key Words: Littoral States- Coastal States, Maritime-Nautical, Legal Regime-Lawful Governance, Choke Points-Sea waterway between two land Points, UNCLOS- UN Convention on the Law of the Sea)
\end{abstract}

Terrestrial land, space and water are three natural elements determines the countries progress. The natural reservoir of ocean equally plays major role of any country's policies and development. Among three largest ocean in the world (Pacific and Atlantic), the Indian Ocean which engulfs one third of the Earth's surface, covers 73.56 million square miles. The amazing borders starting from north the Indian sub-continent, in the west and northwest by the east African coast and Arabian Peninsula respectively; Thailand, the Malaya, Indonesia and Australia are in the east; the southern oceanic latitude $60 \mathrm{~s}$, besides several regional seas. The IOR has nearly seven chokepoints. There are 42 littoral states and at least 2600 cities influenced by this IOR. Around 40 per cent of the coastline comprised which directly or indirectly determines the livelihood of 280 billion of populace of the IOR. Such an impregnable IOR is very significant to address the many nation's maritime security imperatives, therefore, this article intent to analyse the IOR's contemporary security, strategic and development policies.

\section{Maritime Power -A Conceptual Clarity}

Maritime power is an important component of state power and is a key enabler for national growth and development. These aspects have prompted a steady, global shift of attention from land to the seas and an expanding maritime horizon. The maritime strategy of a nation is shaped by the growth of population, industry, infrastructure and politico-economic power along the coast, and the ensuing dependence on the seas for national growth and prosperity. It is a central determinant of a nation's maritime interests and strategy. Although land has been the primary and natural habitat of mankind, and is central to political, economic, military and social activities, the oceans have directly and indirectly influenced events on land. Over the past two centuries, in particular, technological and maritime developments have significantly altered the role and influence of the maritime environment. From a medium of transportation for trade, economy and the projection of power onto land, the oceans have become the primary conduits of international trade and are central to the global economy. The oceans and seabed are increasingly looked upon today as resource providers and critical contributors to national growth and prosperity.

\section{Menace and Security}

Bye and Large, a State's security depends upon geographical features especially sea and deep-sea as great protection. Threats and challenges to a country's maritime interests emanate from traditional and nontraditional sources. The various sources and types of maritime threats must be catered for in the maritime security strategy. The strategic assessment of probable and possible sources of threats to India is a continuous process, and is carried out by various national agencies and the armed forces. The Naval authority continue to monitor all developments impacting the maritime domain, which may affect its roles and responsibilities, and incorporate the same into its strategic and operational plans. The traditional sources refer to states with organised military capability and resources, which harbour adversarial posture and inimical intent towards a country. Hostile actions by such states, in terms of scale, scope and intensity of force that may be applied, would potentially be of a higher order. Traditional sources, therefore, pose a higher level of threat to IOR's security interests. Countering traditional maritime security threats will remain the raison deter of the IOR, especially India's Navy, particularly the way in which it is structured, equipped, modernised, trained and deployed. However, in recent years non-traditional security threats have necessitated the development of a fresh paradigm for maritime security. There has been a steady rise in non-traditional threats, in occurrence and scale, with the lines at times getting blurred with traditional challenges. This is especially the case where non-traditional threats receive cooperation, support and sponsorship from traditional entities. Changes in the nature of non-traditional 
threats and challenges necessitate corresponding changes in strategies, force structures, operating methodology, training, and coordination mechanisms.

\section{Political Conflict at IOR}

Extra-regional powers such as the US, European Union, Japan and China are always taken chance to interfere the geopolitical crisis in many folds. Regional States and Non-State actors also increasingly influence global affairs. The IOR has witnessed at-least 160 political conflicts in five decades, in addition to 12 noted wars including the two World Wars. Throughout ages the IOR is primarily an international through-route. It is rapidly emerging as a strategic global intersection for Geo-strategic, economic, natural resource, and environmental issues. Multiple security, maritime policy, and governance challenges are driving regional and extra-regional players to focus increasing attention on Indian Ocean issues within a complex geopolitical framework where foreign powers and local actors' interests and objectives inextricably intermingle.

\section{Security Scenario at IOR}

Piracy and armed robbery at sea constitute the oldest forms of maritime security threats. These target maritime trade and, therefore, the economy of affected nations. This also put the lives of people working onboard ships at risk, and threaten freedom to use the seas for livelihood and economic growth, affecting the maritime interests of a country. Hence, combating piracy has been great challenge. From 2010 onwards, maritime security in the Indian Ocean continued to be dominated by piracy and armed robbery at sea, specifically hijacking of merchant vessels by well-armed Somalia-based pirates. By the end of 2011, nearly 214 vessels had been attacked, 31 hijacked, while eight vessels remained under capture awaiting release and of payment of ransoms, 497 seafarers had been held captive, and 10 seafarers had lost their life.

Figure -1 Sea Vessels attacked in 2011

\begin{tabular}{|l|l|l|l|l|}
\hline No. vessels attacked & Captive seafarer & Success rate & Warship involved & No. states involved \\
\hline 31 & 497 & $14 \%$ & 45 & 28 \\
\hline
\end{tabular}

Source: Risk Intelligence

Piracy Attack Groups (PAGs) is increasingly well armed, highly motivated by the prospect of very large ransom payments (average payment is currently \$5.4 million), and many are using captured merchant vessels as motherships to stage further attacks. During 2011, there were typically 35-45 warships and auxiliaries deployed in the Indian Ocean on counter-piracy operations drawn from some 28 states, and there remain three dedicated counter-piracy coalition forces - the EU's counter-piracy task force EU Naval Force (otherwise referred to as EU NAVFOR or Operation Atalanta), NATO's Standing Naval Maritime Group (SNMG) 1 and 2 , and Combined Task Force 151 (CTF-151).

Figure-2 Piracy Attack from 2008 to 2013

\begin{tabular}{|l|l|l|l|l|l|l|l|l|l|l|l|}
\hline Jan & Feb & march & April & May & June & July & August & Sept & October & November & December \\
\hline 80 & 44 & 123 & 82 & 79 & 42 & 18 & 28 & 49 & 93 & 86 & 88 \\
\hline
\end{tabular}

Source: Risk Intelligence

\section{Trafficking by Sea}

In spite of various security units illicit sea trading is main stay of some terror groups. Illicit trafficking such as narcotic, weapons, human being in the form of migration is steadily increasing and challenges the IOR countries. Three types of illicit narcotics dominate trafficking in the Indian Ocean is heroin/opiates, amphetamine-type stimulants (ATS), and cannabis. In terms of volume, the majority of narcotics are trafficked by land, most notably Afghani heroin bound for Russia and Europe via Central Asia, the Caucasus, Turkey, and the Balkans. Nevertheless, sea conveyance of narcotics remains substantial. The modus operandi of trafficking and smuggling by sea is transshipment of consignments on the high seas into local craft, which then mingle with dense fishing activity offshore and can land at any of the myriad landing points ashore. The sea route has been in use for human trafficking/smuggling, not only in relation to India's close maritime neighbours, but also across the seas and extended maritime neighbourhood. This places a constant demand on various maritime agencies and their resources. The threat of nuclear material being smuggled from maritime neighbourhood which needs a constant consideration to monitor the maritime spaces. 
Figure-3-Trafficking- Transshipment points

\begin{tabular}{|c|c|c|c|c|}
\hline Narcotics/Opiates & Narcotics/ ATS & $\begin{array}{l}\text { Narcotics } \\
\text { Cannabis }\end{array}$ & $\begin{array}{l}\text { Small arms \& light } \\
\text { weapons }\end{array}$ & $\begin{array}{l}\text { Women/children } \\
\text { /labors }\end{array}$ \\
\hline $\begin{array}{l}\text { India (Mumbai, } \\
\text { Chennai, Calcutta, } \\
\text { Kochi), Kenya } \\
\text { (Mombassa), } \\
\text { Mozambique } \\
\text { (Nacala Porto, } \\
\text { Pemba, Maputo), } \\
\text { Oman (Salalah, } \\
\text { Muscat); South } \\
\text { Africa (Durban), } \\
\text { Tanzania (Dar es } \\
\text { Salaam), UAE } \\
\text { (Jebel Ali) }\end{array}$ & $\begin{array}{l}\text { India(Mumbai, } \\
\text { Chennai,Calcutta, } \\
\text { Kochi), Kenya } \\
\text { (Mombassa), } \\
\text { Mozambique } \\
\text { (Nacala Porto, } \\
\text { Pemba, Maputo), } \\
\text { Oman (Salalah, } \\
\text { Muscat); South } \\
\text { Africa (Durban), } \\
\text { Tanzania (Dar es } \\
\text { Salaam), UAE } \\
\text { (Jebel Ali) }\end{array}$ & $\begin{array}{l}\text { India (Mumbai, } \\
\text { Chennai), Kenya } \\
\text { (Mombassa); } \\
\text { South Africa } \\
\text { (Durban); } \\
\text { Sri Lanka } \\
\text { (Colombo), } \\
\text { UAE (Jebel Ali) }\end{array}$ & 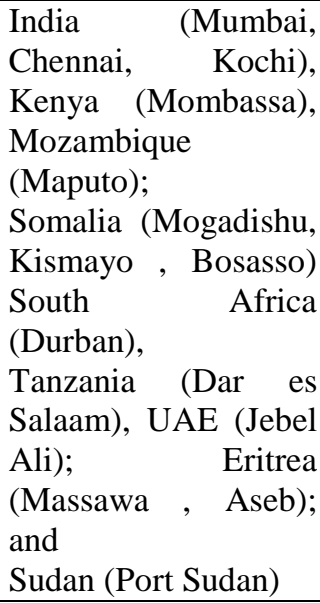 & $\begin{array}{l}\text { India (Mumbai, } \\
\text { Chennai, Calcutta), } \\
\text { Kenya } \\
\text { (Mombassa), Oman } \\
\text { (Salalah, Muscat); } \\
\text { Tanzania (Dar es } \\
\text { Salaam), UAE; } \\
\text { Yemen } \\
\text { (Hodeidah, Mocha, } \\
\text { Red } \\
\text { Sea coast, Hanish } \\
\text { Island group }\end{array}$ \\
\hline
\end{tabular}

Across the IOR, the most common types of weapons trafficked fall into the SALW category. Trafficked weapons in this category include anti-aircraft guns (e.g., ZU-23-2); anti-personnel mines; anti-tank guided missiles (e.g., Malyutka AT-3 Sagger); anti-tank mines (e.g., TMA- 5, YM-III); assault rifles (e.g., AK47, AK-74, G-3s, FN FAL, M-16); C-4 plastic explosives; hand grenades; handguns/side arms; heavy machine guns (e.g., DShK); man-portable air defence systems (MANPADS) (e.g., SA-7,\& Strela-2); man-portable machine guns (e.g., PKM, RPK); mortars (e.g., 60mm, 80mm, and $120 \mathrm{~mm}$ variants); rocket-propelled grenades (e.g., RPG-7, RPG-18); sniper rifles (e.g., 7.62mm SVD); surface-to-surface rockets (e.g., $122 \mathrm{~mm}$ and $107 \mathrm{~mm}$ Katyusha and Grad); TNT; and so on.

\section{Pakistan Sponsored Maritime Terror}

The unsuccessful AQIS raid left 10 terrorist dead including a former Pakistan Navy officer Awais Jakhrani, who is reported to have had links with Jihadi elements. Further interrogations have led to the arrest of three other Pakistan Navy personnel in Quetta in Baluchistan who were attempting to escape to Afghanistan. The attack exposed chinks in Pakistan's naval defence particularly strategic infrastructure which host millions of dollars' worth of naval hardware such as ships, submarines and dockyards. It is important to mention that this is not the first time that terrorist groups have managed to penetrate Pakistan's naval defences. In the past there have been at least two other attacks on highly sensitive naval platforms and on foreign naval personnel. In a year, 14 persons including 11 French naval engineers working on the submarine project were killed and 23 others were injured when an unidentified man blew himself up with his car after ramming it into a 46-seater Pakistan Navy bus outside the Karachi Sheraton Hotel.

The second attack was on Pakistan's naval air base Mehran and was the handiwork of the Tehrik-i-Taliban Pakistan (TTP), a coalition of militant groups based in the tribal areas of northwestern Pakistan. As many as 15 attackers from the 'Brigade 313' of the Al Qaeda- Harakat-ul-Jihad-al-Islami group led by Ilyas Kashmiri, took part in the operation which left 18 naval personnel killed, 16 wounded and two US built P-3C Orion maritime surveillance aircraft destroyed. Significantly, the attackers had good knowledge of the naval base including security arrangements, exit and entry points, and the details of the hangers and aircraft. These attacks showcase that Karachi is a staging point for maritime terrorism particularly for those groups who have taken a liking for naval targets.

In fact, Karachi has been labeled as the 'terror capital' and is a paradise for terrorists, gunrunners, and drug smugglers. The city is rife with ethnic strife and home to crime syndicates particularly Dawood Ibrahim who is wanted in India for a number of crimes including the 1993 Mumbai blasts. The city is also known for the 'point of departure' for Mumbai terror attacks by the Lashkar-e-Taiba (LeT) who sailed from Karachi on three boats and later hijacked the Kuber an Indian fishing off Porbandar, on the Gujarat coast and landed on unsecured waterfronts in south Mumbai. Perhaps the most discomforting issue of the attacks is that Jihadi groups have dared the Pakistan Navy and caused enormous damage to its reputation, morale and material.

They have penetrated the rank and file of the Pakistan Navy and the attacks on PNS Mehran and PNS Zulfiqar were planned and executed with the help of naval personnel. Referring to the PNS Zulfiqar attack, Pakistan Defence Minister Khawaja Asif made a statement in the Parliament that the attack could not have taken place "Without assistance from inside, these people could not have breached security," The entry of Jihadi elements is sure to cause suspicion among the other multinational partners with whom the Pakistan Navy works 
closely, particularly the United States. It is believed that some elements in the Pakistan Navy were upset with the US its raid deep into Pakistan which led to the killing of Osama bin Laden.

The above attacks also have a bearing on the safety and security of Pakistan's nuclear installations. In the absence of a nuclear submarine, the Pakistan Navy has drawn plans to build a rudimentary sea-leg of the nuclear triad with ships and conventional AIP-submarines fitted with nuclear weapons. Any attempt to attack or hijack these platforms and use them as 'bargain chip' for any Jihadi agenda would cause grave damage to global security. However, it is fair to say that the Pakistan Navy is a responsible force and has taken part in a number of multinational operations in the Arabian Sea-Gulf of Aden fighting pirates and terrorists under the US led multinational coalition force TF-151. It has also been the force commander of the coalition forces during these operations and its professionalism has received accolades. The Pakistan naval authorities would have to sanitize the force and rebuild its image of a highly professional fighting force free of radical elements and jihadi thought with a strong commitment to serve national interests and Pakistan's international commitments to ensure order at sea.

\section{Marine Legal Regime}

Such a largest Ocean region has been governed by UN Convention on the Law of the Sea (UNCLOS1982), established a new order of the oceans that promised the stability needed to protect sovereignty, provide for national security, promote trade and development, and safeguard the marine environment. UNCLOS defines ocean zones and the rights and obligations of states within those zones. It establishes organizations to carry out collective responsibilities for both defining the boundaries of national jurisdiction and managing mineral resources beyond those limits. It also provides alternative processes for conflict resolution, with some issues subject to mandatory settlement of disputes. UNCLOS defines ocean zones rights and obligations of states within those zones. In a broad sense, the law of the sea both under the convention and as implemented through other treaties, organizations, and agreements provides the stable legal order necessary to manage the increasingly intense development of the ocean and its resources. This is particularly important in the Indian Ocean and the South China Sea, where overlapping claims of sovereignty and sometimes dysfunctional governments are placing the international legal regime under great stress.

Figure-4-Snap Shots -Ocean Zones- Rights Responsibilities

\begin{tabular}{|c|c|c|}
\hline UNCLOS & High lights- Main features & $\begin{array}{l}\text { IOR's } \\
\text { Response }\end{array}$ \\
\hline $\begin{array}{l}\text { Territorial } \\
\text { Sea }\end{array}$ & $\begin{array}{l}\text { The coastal seas extending as far as } 12 \text { miles from shore, in which the coastal } \\
\text { state has sovereign authority, subject to the recognition of the right of } \\
\text { innocent passage for ships on their way from one location to another }\end{array}$ & $\begin{array}{l}\text { Agreed and } \\
\text { adopted }\end{array}$ \\
\hline $\begin{array}{l}\text { Contiguous } \\
\text { Zone }\end{array}$ & $\begin{array}{l}\text { An area extending } 12 \text { miles beyond the territorial sea, in which the coastal } \\
\text { state may enforce its fiscal, customs, immigration, sanitary, and security } \\
\text { laws. }\end{array}$ & $\begin{array}{l}\text { Agreed and } \\
\text { adopted }\end{array}$ \\
\hline $\begin{array}{l}\text { Exclusive } \\
\text { Economic } \\
\text { Zone (EEZ) }\end{array}$ & $\begin{array}{l}\text {-The seas beyond the territorial sea extending to } 200 \text { nautical miles, in which } \\
\text { the coastal state has the sovereign right to manage, exploit, and protect } \\
\text { mineral and living resources, subject to providing access to unused portions } \\
\text { of what the coastal state determines to be the maximum allowable catch of } \\
\text { the living resources. } \\
\text {-Other states are guaranteed high seas navigation rights and the right to lay } \\
\text { and maintain cables and pipelines }\end{array}$ & $\begin{array}{l}\text { Agreed and } \\
\text { adopted }\end{array}$ \\
\hline $\begin{array}{l}\text { Continental } \\
\text { Shelf }\end{array}$ & $\begin{array}{l}\text { Both the seabed of the EEZ and the areas of the seabed beyond the EEZ that } \\
\text { meet geological requirements specified in UNCLOS. } \\
\text { The coastal state manages the resources of the continental shelf (and shares } \\
\text { revenues derived from exploitation of mineral resources of the shelf beyond } \\
\text { the EEZ) with the international community. }\end{array}$ & $\begin{array}{l}\text { Agreed and } \\
\text { adopted }\end{array}$ \\
\hline High Seas & $\begin{array}{l}\text { The waters beyond the EEZ in which vessels and activities are under the } \\
\text { authority of the flag state, and subject to only a limited number of } \\
\text { international prohibitions, such as measures outlawing piracy and the slave } \\
\text { trade. }\end{array}$ & $\begin{array}{l}\text { Agreed and } \\
\text { adopted }\end{array}$ \\
\hline The Area & $\begin{array}{l}\text { The portion of the ocean floor beyond the limits of national jurisdiction. } \\
\text { Mineral resources of the Area are managed by the International Seabed } \\
\text { Authority, as established by UNCLOS. }\end{array}$ & $\begin{array}{l}\text { Agreed and } \\
\text { adopted }\end{array}$ \\
\hline $\begin{array}{l}\text { International } \\
\text { Straits }\end{array}$ & $\begin{array}{l}\text { Straits that are used in international navigation regardless of whether they are } \\
\text { sufficiently narrow to otherwise be considered territorial seas subject to } \\
\text { innocent passage. }\end{array}$ & $\begin{array}{l}\text { Agreed and } \\
\text { adopted }\end{array}$ \\
\hline
\end{tabular}




\begin{tabular}{|l|l|l|}
\hline & $\begin{array}{l}\text { International straits are subject to the regime of Transit Passage, in which } \\
\text { ships and aircraft may pass through or over international straits in their } \\
\text { "normal mode" without the restrictions imposed on innocent passage. }\end{array}$ & \\
\hline $\begin{array}{l}\text { Archipelagic } \\
\text { Waters }\end{array}$ & $\begin{array}{l}\text { Those waters within boundary lines drawn to encompass the islands of } \\
\text { archipelagic states. Passage through archipelagic waters is subject to adopted } \\
\text { conditions similar to Transit Passage in designated sea lanes and innocent } \\
\text { passage in other areas of the waters }\end{array}$ & $\begin{array}{l}\text { and } \\
\text { pand }\end{array}$ \\
\hline
\end{tabular}

The UN's Fish Stocks Agreement was opened for signature in 1995 and it came into force in 2001. The agreement provides the framework for the establishment and operation of regional agreements to manage high seas and straddling fish stocks in accordance with UNCLOS. As an example, the Southern Indian Ocean Fisheries Agreement (SIOFA) is a regional agreement negotiated under the Fish Stocks Agreement to address high seas fisheries in the southern Indian Ocean region.

\section{Maritime Competition and Networks}

The Indian Ocean Rim countries have establishment a number of multilateral maritime mechanisms to address non-traditional security threats and challenges confronting the region. The Indian Ocean Rim-Association of Regional Cooperation (IOR-ARC), rechristened as Indian Ocean Rim Association (IORA), is the only pan Indian Ocean economic grouping and brings together countries straddling three continents i.e. Africa, Asia and Australia. In recent times it has begun to address maritime security issues.

The Indian Ocean Naval Symposium (IONS) is a 35-member of Indian Ocean security apparatus which facilitates exchange of views among the naval professionals to evolve common understanding of maritime security issues in the region. Likewise, Milan (confluence) is a gathering of navies from India's extended neighbourhood of Southeast Asia, Australia and New Zealand that aims to develop cooperative mechanisms. The 2014 Milan at Port Blair in the Andaman \& Nicobar Islands in the Bay of Bengal was significant from the perspective that 17 navies participated including two from Africa (Kenya and Tanzania), three Indian Ocean island nations (Mauritius, Maldives and Seychelles) and the navies of Philippines and Cambodia made their debut.

In the Indian Ocean, each coastal state is allocated a Search and Rescue Region (SRR) and they have set up national systems and arrangements such as Rescue Co-ordination Centres (RCC) and Rescue Sub-Centres (RSC), SAR facilities and communications in the area, including detailed plans for conducting SAR operations. The Indian Ocean is also divided into a number of sea spaces called NAVAREAS (VII- South Africa; VIII S-Mauritius; VIII N- India; XI-Pakistan; and XAustralia). These are administered by the coordinator country that is responsible for providing vital navigation warnings, including weather data. A number of international conventions on SAR such as the 1974 Convention for the Safety of Life at Sea (SOLAS), 1979 International Convention on Maritime Search and Rescue (SAR), 1982 LoS Convention, and the International Aeronautical and Maritime Search and Rescue (IAMSAR) have been adopted by member states. The Indian Ocean Rim Association (IORA), a pan-Indian Ocean multilateral organisation, has highlighted the need for regional efforts to build SAR capacity and capability. The international efforts to locate the wreckage of Malaysian Airlines flight MH 370 which went missing over the southern Indian Ocean nearly seven months ago have continued unabated. Till such time the debris and the black box is located, the cause of the accident will remain a mystery; but the unfortunate incident brought to fore the challenges posed by the underwater domain and also the national, regional and global limitations of search and rescue (SAR). Post the MH 370 tragedy, a number of conferences, workshops and symposia have highlighted the gaps in SAR in the Indian Ocean and the issue has been high on the national agenda as also in multilateral organisations.

\section{Sea Governing Laws in India}

On September 21, 2016, the Union Cabinet approved the enactment of the Admiralty (Jurisdiction and Settlement of Maritime Claims) Bill 2016. The Bill repeals five obsolete British statutes on admiralty jurisdiction in civil matters, namely, (a) Admiralty Court Act, 1840 (b) Admiralty Court Act, 1861, (c) Colonial Courts of Admiralty Act, 1890, (d) Colonial Courts of Admiralty (India) Act, 1891, and (e) the provisions of the Letters Patent, 1865, applicable to the admiralty jurisdiction of the Bombay, Calcutta and Madras High Courts.

The maritime industry has been highlighting the need to update India's Admiralty Laws so as to be responsive to the needs of the industry and ensure that maritime disputes are disposed expeditiously and effectively. The Admiralty law governs maritime questions and offenses. It is a body of both domestic law governing maritime activities and private international law governing the relationships between private entities that operate vessels on the oceans. It deals with matters including marine commerce, marine navigation, marine salvaging, shipping, sailors, and the transportation of passengers and goods by sea. Admiralty Courts dated to at least 1360s during the reign of Edward III of England. The Admiralty court's jurisdiction historically embraced 
all crimes and offenses involving English ships or crews that were committed at sea or along the English coast outside the borders of any county. Although it originally dealt only with matters of discipline in the English fleet and with cases of piracy and prizes (ships and goods captured at sea), the court progressively acquired some civil jurisdiction over mercantile and shipping disputes. Due to jurisdictional dispute with the civil and the criminal law courts, the Admiralty court progressively concentrated on marine cases involving shipping, collisions, and salvage.

\section{Prominent Features of Indian Maritime Bill, 2016- Highlights}

- The Bill confers admiralty jurisdiction on High Courts located in all coastal states and this jurisdiction extends up to the territorial waters.

- The jurisdiction is extendable, by a Central Government notification, up to the exclusive economic zone or any other maritime zone of India or islands constituting part of the territory of India. It applies to every vessel irrespective of place of residence or domicile of owner.

- Inland vessels and vessels under construction are excluded from its application, although the Central Government is empowered to make it applicable to these vessels by a notification if necessary.

- It does not apply to warships and naval auxiliary vessels used for non-commercial purposes. The jurisdiction is for adjudicating on a set of maritime claims listed in the Bill.

- In order to ensure security against a maritime claim, a vessel can be arrested in certain circumstances.

- The liability in respect of selected maritime claims on a vessel passes on to its new owners by way of maritime lien subject to a stipulated time limit.

- In respect of aspects on which provisions are not laid down in the Bill, the Civil Procedure Code, 1908 is applicable.

The Government of India has given an impetus for enhancing mercantile trade through its focus on accelerated development of the maritime infrastructure. Along with infrastructure, a holistic review of the enabling legal framework for mercantile trade and maritime practices is also essential. Legislative processes need to be critically reviewed to avoid inordinate delay in the enactment of statutes. The Admiralty Bill 2016 has been in the making for nearly 30 years. This long awaited Admiralty Legislation yet to be approved, main features of the bill is highlighted above.

To assess the status of the country's coastal security (MHA) Ministry of Home Affairs organised a review meeting on June 16, 2016 in Mumbai. One of the suggestions proposed at the meeting was the establishment of a Central Marine Police Force (CMPF) to patrol the coastal waters. The suggestion to raise a CMPF was made by Maharashtra, Honourable, Chief Minister, Devendra Fadnavis. And it was reportedly supported by chief ministers of at least four other coastal States. The suggestion to raise a CMPF is not new and many coastal States and Union Territories have been asking for a centrally funded marine police force to address the shortfall of manpower in coastal police stations. In fact, the very suggestion for raising a CMPF reflects the reluctance of the coastal States and Union Territories to shoulder the responsibility of coastal security. A telling example of their reluctance is the uneven implementation of the Coastal Security Scheme (CSS) introduced by the Union Government in for strengthening coastal security.

The maritime security strategy addresses this gap by complementing the evolving security dynamics in the Indian Ocean Region and reflecting a bold Indian navy with a renewed outlook on India's maritime security needs a special strategy. The security architecture in maritime Asia along with the rise of China is compelling India to define its strategic interests and review its maritime policy. The maritime security strategy precisely does the same. It carries a larger strategic angle than its predecessors and attempts to embody an Indian naval vision for the region.

There were some 102,194 merchant vessels listed as operational in the global fleet, amounting to an aggregate tonnage of 1.276 million DWT (deadweight tonnage). Of this, 35.8 percent were bulk carriers, 35.3 percent were oil tankers, 13.3 percent container vessels, and 8.5 percent were represented by general cargo ships.

Figure-5-Fleet Ownership

\begin{tabular}{|l|l|l|l|l|l|l|l|l|l|l|l|}
\hline $\begin{array}{l}\text { Countr } \\
\text { y }\end{array}$ & No ships & $\%$ & Country & $\begin{array}{l}\text { No } \\
\text { ships }\end{array}$ & $\%$ & Country & $\begin{array}{l}\text { No } \\
\text { ships }\end{array}$ & $\%$ & Country & $\begin{array}{l}\text { No } \\
\text { ships }\end{array}$ & \begin{tabular}{l}
$\%$ \\
\hline Greek
\end{tabular} 3889 \\
\hline
\end{tabular}

Source: Indian Defense Studies

More than 90 percent of shipbuilding was undertaken in three Asian countries, South Korea, which accounted for 37.3 percent of new gross tonnage, China (28.6 percent), and Japan (24.6 percent). Yards in all of the world's remaining shipbuilding countries combined to account for only 9.6 percent of construction. The 
three main shipbuilding countries specialize in different vessels. South Korea focuses on container ships, oil tankers and, to a lesser extent, specialized LNG carriers, while China dominates the dry bulk carrier market, partially due to the fact that its yards are not yet as technically advanced as those of South Korea and Japan. The Japanese yards, meanwhile, concentrate primarily on oil tankers and a small number of container vessels.

There is also a significant presence of Indian nationals in the international seafaring community, operating on both Indian and foreign ships, with approximately $6.6 \%$ of the world's merchant mariners being Indian. The overall safety and security of Indian seaborne trade and seafarers, on both Indian and foreign ships, require that international shipping and sea routes remain safe, secure and free for navigation and legitimate uses. India has 12 major and 200 non-major ports, spread along its East and West coasts, as also its islands. Ports play a vital role in the overall economic development of the country, as they provide the trade hubs where sea and land trade routes meet and the cargo moves from one medium into the other. These are both the destination and the source of the maritime leg of global supply chains. The cargo handling capacity of the ports, the infrastructure in these ports and cities, and the development of support services therein have a direct link to the economy. These are presently being developed under India's Sagarmala project, which is estimated to boost the nation's GDP growth by $2 \%$. India is the second largest producer of fish in the world, accounting for $5.68 \%$ of the world's fish production. There are about 2, 45,000 fishing vessels in India and the annual marine fish landings amount to about four million metric tons. India's fisheries sector contributes about one percent of the national GDP and $4.6 \%$ of the agricultural GDP. It is estimated that the fishing communities along the coast comprise over 8, 60,000 families and number about four million, with livelihood from fishing extending to approximately 14.5 million people.

Figure-6-Growth of Indian Shipping

\begin{tabular}{|l|l|l|l|l|l|l|l|l|}
\hline Year & 1980 & 1985 & 1990 & 1995 & 2000 & 2005 & 2010 & 2015 \\
\hline Coastal Vessels & 58 & 95 & 162 & 219 & 332 & 485 & 700 & 846 \\
\hline Overseas Vessels & 325 & 273 & 256 & 251 & 237 & 236 & 340 & 358 \\
\hline Total & 383 & 368 & 418 & 470 & 549 & 721 & 1040 & 1204 \\
\hline
\end{tabular}

Source: Indian Defense Studies

There are 74 AIS receivers along the Indian coast and these are capable of tracking 30,000 to 40,000 merchant ships transiting through the Indian Ocean. The AIS is mandatory for all merchant ships above 300 tons DWT and it helps monitoring agencies to keep track of shipping and detect suspicious ships. However the AIS a vulnerable to 'data manipulation'. According to a recent study, the international shipping manipulates AIS data for a number of reasons, and the trends are quite disturbing. In the last two years, there has been 30 per cent increase in the number of ships reporting false identities. Nearly 40 per cent of the ships do not report their next port of call to prevent the commodity operators and to preclude speculation. Interestingly, there is growing tendency among merchant ships to shut down AIS, and 'go dark' and spoofing (generating false transmissions) is perhaps the most dangerous. It can potentially mislead the security forces who have to respond to such targets and on finding none, leads to loss and wastage of precious time and human effort which adversely affects operational efficiency of the maritime security forces.

The period after the defeat of the LTTE, there has seen increased incidence of the Indian fishermen coming in to conflict with their counter parts in Sri Lanka and also with the Sri Lankan Navy. There have been allegations and counter allegations about use of excessive force and even fire arms to prevent fishermen from poaching. From the Indian fishermen point of view, historically, the contested waters belonged to India and they have every right to fish in the traditional waters. Having demarcated the maritime boundary with Sri Lanka in 1974, wherein, Kachchativu was gifted to Sri Lanka, the Indian fishermen have been debarred from fishing around that rich fishing grounds that Island leading to skirmishes and incidents. It is not that only Indian fishermen are guilty of trespassing, the Indian Ocean has witnessed intrusions by fishermen of Pakistan, Bangladesh, Thailand, Myanmar and Sri Lanka who do cross in to each other's territory while looking for fish. This remain a great challenge with security overtones.

Although the Indian security forces had responded swiftly to '26/11 Mumbai attack', but it exposed three significant cracks in India's maritime security calculus, the porous nature of India's coastline; the inadequate surveillance of the maritime domain; and lack of inter-agency coordination. Post the 26/11 attacks, that have sought to manage resource development in the region. Indian government specially, Indian Navy undertook a number of proactive measures to restructure coastal security and push the defensive perimeter further away from the coast into the seas. One of the most significant achievements has been the integration of all maritime stakeholders, including several State and Central agencies into the new coastal security mechanism. Indian Navy has established four Joint Operations Centers (JOC) at Mumbai, Visakhapatnam, Kochi and Port Blair. 
Figure -7-Indigenous Security Vessel Capacity

\begin{tabular}{|l|l|}
\hline $\begin{array}{l}\text { Indigenous Aircraft Carrier (IAC) } \\
\text { INS Vikrant built at Cochin Shipyard Limited } \\
\text { (CSL), Kochi. }\end{array}$ & $\begin{array}{l}\text { Project 15A Indigenously designed, 3 ships. By } \\
\text { Mazagon Docks Limited (MDL), Mumbai. INS } \\
\text { Kolkata commissioned in 2014 }\end{array}$ \\
\hline $\begin{array}{l}\text { Project 15B,4 ships. Project 15A. Under } \\
\text { construction at MDL, the first ship INS } \\
\text { Visakhapatnam was launched in 2015. }\end{array}$ & $\begin{array}{l}\text { Project 17A Seven stealth frigates follow-on to Project } \\
17 \text { (Shivalik class). Four ships will be constructed by } \\
\text { MDL and three ships by Garden Reach Shipbuilders } \\
\text { and Engineers (GRSE). }\end{array}$ \\
\hline $\begin{array}{l}\text { Project 28 Four ASW stealth corvettes are being } \\
\text { constructed by GRSE, Kolkata. Indigenously } \\
\text { designed, the first ship, INS Kamorta was } \\
\text { commissioned in 2014 and the fourth launched in } \\
\text { 2015. }\end{array}$ & $\begin{array}{l}\text { Project 75 Six Scorpene submarines are under } \\
\text { construction at MDL in collaboration with DCNS of } \\
\text { France. The first submarine, INS Kalvari, was } \\
\text { launched in 2015. }\end{array}$ \\
\hline $\begin{array}{l}\text { Project 75(I) This project envisages construction } \\
\text { of six submarines in Indian shipyards with } \\
\text { foreign collaboration }\end{array}$ & $\begin{array}{l}\text { Naval Offshore Patrol Vessel (NOPV) Five ships are } \\
\text { under construction at Pipavav Shipyard, Gujarat. }\end{array}$ \\
\hline $\begin{array}{l}\text { Training Ship - Three ships are under } \\
\text { construction at ABG Shipyard, Surat. }\end{array}$ & $\begin{array}{l}\text { Survey Vessel - Order for six catamaran hull survey } \\
\text { vessels has been placed on Alcock Ashdown, } \\
\text { Bhavnagar. The first ship, INS Makar, is already in } \\
\text { service. }\end{array}$ \\
\hline $\begin{array}{l}\text { Landing Craft Utility (LCU) Eight LCUs are } \\
\text { under construction at GRSE. Four of these have } \\
\text { been launched. }\end{array}$ & $\begin{array}{l}\text { Fast Attack Craft (FAC) Four FACs are under } \\
\text { construction at GRSE. Three of these have been } \\
\text { launched }\end{array}$ \\
\hline $\begin{array}{l}\text { Immediate Support Vessel (ISV) Order for 14 } \\
\text { ISVs was placed on SHM Shipcare, Mumbai, } \\
\text { and 11 of these have been commissioned. }\end{array}$ & $\begin{array}{l}\text { Light Combat Aircraft (Navy) The first prototype } \\
\text { (NP1) successfully completed ski-jump tests at the } \\
\text { Shore-Based Test Facility (SBTF) at Goa in 2014. }\end{array}$ \\
\hline $\begin{array}{l}\text { Source: Indian Annual report, Government of India, 2014 } \\
\text { Sal }\end{array}$
\end{tabular}

\section{MSR Strategy and India's Response}

It was the Maldives's turn to receive a sermon on the Maritime Silk Road (MSR) from China. Chinese President Xi Jinping invited Maldivian President Abdulla Yameen to participate in the 21st Century MSR, expand cooperation in tourism, trade and infrastructure, and enhance maritime cooperation. Apparently Yameen assured Xi that the country would "respond to the Chinese initiative." Ali Hameed, former vice foreign minister of the Maldives, too had stated that the MSR was of interest to the Maldives. Earlier, Xi had approached Sri Lanka to consider the MSR, and Colombo indicated that it would actively examine the proposal. The MSR was also raised during Indian Vice President Hamid Ansari's visit to China a few months ago. Unlike in Sri Lanka and the Maldives, the MSR has sent the Indian strategic community into a tizzy. A number of articles, commentaries, discussions and sound bites have concluded that the MSR is nothing but a Chinese ploy to get a naval 'foothold' in the Indian Ocean and reflects China's creeping influence in the region. These reactions are quite natural given that China has aggressively pursued the agenda of building maritime infrastructure in friendly countries such as Pakistan (Gwadar), Sri Lanka (Hambantota) and now the Maldives - that are seen as bases/facilities to support People's Liberation Army Navy's future operations in the Indian Ocean and also the Chinese attempt to 'encircle' India. However, it will be useful to examine the MSR through the prism of maritime infrastructure development and explore if India can leverage the MSR to its advantage. China has developed a sophisticated concept of marine economy that has been facilitated by its long coastline. Nearly 40 per cent of the Chinese population, 5 per cent of cities, 70 per cent of GDP, 84 per cent of direct foreign investment and export products are generated within $200 \mathrm{~km}$ of coast.

Figure-8-India's Borderline Maritime Covenant

\begin{tabular}{|c|c|c|c|c|}
\hline $\begin{array}{l}\text { Delimitation } \\
\text { Continental }\end{array}$ & $\begin{array}{l}\text { Bilateral } \\
\text { Agreements }\end{array}$ & $\begin{array}{l}\text { Trilateral } \\
\text { Agreements }\end{array}$ & $\begin{array}{l}\text { Historic } \\
\text { Waters }\end{array}$ & $\begin{array}{l}\text { Maritime } \\
\text { Silk Rout }\end{array}$ \\
\hline $\begin{array}{l}\text { Indonesia- } \\
1974,1997 \\
\text { Thailand-1978 }\end{array}$ & $\begin{array}{l}\text { Sri Lanka-1977 } \\
\text { Maldives-1978 } \\
\text { Myanmar-1987 } \\
\text { Thailand-1996 } \\
\text { Bangladesh- } \\
2014\end{array}$ & $\begin{array}{l}\text { Sri Lanka, } \\
1976 \\
\text { Indonesia, } \\
1979 \\
\text { Thailand, } \\
1995\end{array}$ & $\begin{array}{ll}\text { Sri Lanka- } \\
1984\end{array}$ & $\begin{array}{l}\text { China-2013 } \\
\text { HADAR(humanitarian } \\
\text { assistance and } \\
\text { disaster response }\end{array}$ \\
\hline
\end{tabular}


Today, China figures among the top countries in shipbuilding, ports (particularly container cargo), shipping, development of offshore resources, inland waterways, marine leisure tourism, and not to forget it is one of the top suppliers of human resources who are employed by international shipping companies. China's shipbuilding capacity is notable and is supported by plentiful of cheap labour and domestic ancillary industry which is endowed with exceptional engineering skills. Seven of the top ten global container ports are in China and the Chinese shipping fleet of 6,427 vessels ranks second behind Japan with 8,357 ships. Similar successes also seen in China's fisheries production which is projected to reach about 69 metric tons by 2022 and it will continue to be top world exporter with 10 metric tons by 2022. Likewise, China ranked third as a tourist destination in 2012. The coastal regions are dotted with marinas, water sport parks and beach resorts and Sanya, Qingdao and Xiamen are home to the growing yacht and luxury boating industry.

\section{Blue Economy by Maritime Capital}

Maritime capital is commonly understood as blue economy which covers the range of economic activities related to the maritime domain, including for ports, coastal infrastructure, shipping, fishing, seaborne trade, offshore energy assets, undersea pipelines and cables, and seabed resources. These have been growing in importance and value for IOR's. Maintenance of a secure maritime environment, which enables unhindered pursuit of these economic activities, is an essential purpose of the maritime security strategy. Petroleum exists in abundance in the IOR. Crude oil and natural gas remain unquestionably the most important raw material exports from the region. In short, the global economy would not function without them. Much has been written on the nature and productivity of the largest reserves. When viewed in an aggregated sense, the total oil and gas reserves held by IOR states as a percentage of the entire world's proven reserves are impressive. IOR states have more than 58 percent of the world's proven reserves and more than 46 percent of gas reserves. When one considers these facts and the inescapable importance of the SLOCs in the Indian Ocean connecting Asia, Europe, and Africa for the conveyance of petroleum, the significance of the IOR to the rest of the world is startling.

India's energy security has a vital role in national development, and is highly dependent on the seas. Nearly $80 \%$ of the country's crude oil requirement is imported by sea, using the ISLs across the Indian Ocean. Another $11 \%$ of national crude oil requirement is met from offshore energy sources within the Indian EEZ. Offshore gas fields also contribute to $80 \%$ of India's domestic natural gas production. In addition, India has built up substantial refining capacity and exports refined petroleum products to many other countries by sea. The products of the petroleum industry account for about $15 \%$ of our Gross Domestic Product (GDP). Taking into account the total oil imports by sea, offshore oil production and petroleum exports, the country's cumulative 'sea dependence' for oil is estimated to be about $93 \%$. India has sovereign rights for exploitation of living and non-living resources in its EEZ, which essentially comprise the offshore energy sector and fisheries sector at present. India has been promoting exploration and production of hydrocarbon energy in its EEZ under the New Exploration Licensing Policy (NELP), which has seen expanded investments in recent years. Merchandise trade constitutes $42 \%$ of India's GDP, and can be expected to increase in the future. More than $90 \%$ of India's international trade by volume and over $70 \%$ by value is carried over the seas.

Figure-9-IOR's Oil and Gas Production in \%

\begin{tabular}{|l|l|l|l|l|l|l|l|}
\hline IOR's & Saudi Arabia & India & Iran & Australia & Indonesia & Myanmar & Malaysia \\
\hline Oil\% & 19.8 & 0.5 & 10.3 & 0.3 & 0.3 & 0.05 & 0.4 \\
\hline Gas\% & 3.92 & 0.57 & 15.57 & 1.64 & 1.58 & N.A & 1.24 \\
\hline
\end{tabular}

There is also a significant presence of Indian nationals in the international seafaring community, operating on both Indian and foreign ships, with approximately $6.6 \%$ of the world's merchant mariners being Indian. The overall safety and security of Indian seaborne trade and seafarers, on both Indian and foreign ships, require that international shipping and sea routes remain safe, secure and free for navigation and legitimate uses. There are three known classes of hard minerals on the world's deep seabed, Polymetallic nodules of manganese and iron oxides enriched in nickel, copper, cobalt, and rare earth elements are found on the abyssal plains; Cobalt crusts consisting of iron and manganese oxides enriched in cobalt and rare earth elements, and found on the slopes of seamounts; and Polymetallic sulfides of copper and zinc, sometimes enriched with gold, that are found near spreading centers and subduction zones which considerably increase the blue economy.

Fishing

Commercial and artisanal fisheries sustain the livelihood of more than 38 million people worldwide. In the Indian Ocean, fish production increased drastically from 8,61,000 tons into 11.3 million tons in 2010. But while other world oceans are nearing their fisheries limit, the United Nations Food and Agriculture Organization 
(FAO) judges that, in certain areas, the Indian Ocean's resources have the potential to sustain increased production. The countries of the east Indian Ocean represent a significant proportion of world fisheries, although most commercial and artisanal activity takes place in coastal zones rather than in deep water. The Indian Ocean is home to 45 percent of the world's fishers and brings in catches of 7 million tons of fish per year, or 8 percent of total world fish production. Most of this catch is harvested close to shore, placing so much strain on coastal stocks that fishers have been forced to venture further out to sea and even into the exclusive economic zones (EEZs) of neighboring nations. Even so, this trend of fishing far from shore is still in its early stages. Deepwater catches represent less than 6 percent of total catches in Indonesia and 10 percent in Malaysia, for example, overexploitation and overcrowding of coastal fisheries, deep-water fish stocks represent a potential new frontier for commercial and artisanal fisheries in the region.

\section{Maritime Environment Impediments}

Oceans and coastal regions are coming under rising environmental pressures worldwide. These growing stresses include habitat destruction and biodiversity loss, land-based and marine pollution, overexploitation of resources, and the increasing impacts of greenhouse gas emissions and global climate change. No area of the ocean escapes these strains, and a large part of the world's seas nearly 41 percent is vulnerable and suffers from multiple stresses. Significant portions of the Indian Ocean now figure among the most highly impacted marine ecosystems on Earth, and the Indian Ocean region (IOR) littoral countries count among the world most vulnerable to coastal environmental risks.

\section{Marine Pollution}

The oceans are not free from pollution nor are they insensitive to the effect of pollutants. As long as people use the sea as a universal sink, the pollution up to a certain extent. It is very difficult to avoid. The prominent marine pollutants and the consequences of their marine disposal are given in detail.

Figure-10 Marine Pollution

\begin{tabular}{|l|l|l|l|l|}
\hline Oil Pollution & Heavy Metal Pollution & $\begin{array}{l}\text { Agricultural } \\
\text { Wastes }\end{array}$ & $\begin{array}{l}\text { Domestic } \\
\text { wastes }\end{array}$ & $\begin{array}{l}\text { Sensitive/Fragile } \\
\text { Environments }\end{array}$ \\
\hline $\begin{array}{l}\text { Accidental oil } \\
\text { spill(Torrey Canyon, } \\
\text { Ennore oil spill) }\end{array}$ & $\begin{array}{l}\text { toxic heavy metals- } \\
\text { mercury (Hg), cadmium } \\
(\mathrm{Cd}) \text { and lead } \\
(\mathrm{Pb}),\end{array}$ & $\begin{array}{l}\text { Agricultural } \\
\text { Wastes- } \\
\text { chemical- } \\
\text { pesticides }\end{array}$ & $\begin{array}{l}\text { Sewage/house } \\
\text { hold drains }\end{array}$ & $\begin{array}{l}\text { coral } \\
\text { reefs; mangroves } \\
\text { sea grass beds- }\end{array}$ \\
\hline
\end{tabular}

Almost all the countries in the Indian Ocean region are signatories to the 1973 MARPOL convention and the 1978 protocol. These have resulted in the establishment of reception facilities for oily bilges, ballasts and sludges at almost all the major ports. With more and more such facilities becoming available in ports, the oil pollution in the Northern Indian Ocean can be expected to reduce further.

The term maritime environment in this strategy refers to the multi-dimensional space and conditions therein, across the maritime zones and extending to India's areas of maritime interest. It takes into consideration the seamless connectivity in the maritime domain, wherein there can be free flow of influences, including instability and insecurity, across different maritime areas. In recent years, there has been an increase in the movement and spread of terrorism, piracy, arms/ drug/ human trafficking and smuggling by sea. India's maritime environment is, accordingly, affected by security threats and challenges spread across its maritime neighbourhood and adjacent areas. Hence, it is important to shape favourable and positive conditions across the broader maritime environment, towards enhancing our own maritime security and for supporting our national interests.

A favourable maritime environment entails conditions of security and stability at sea, with various threats remaining at a low level. A positive maritime environment implies conditions wherein any rise in threats can be prevented or contained. The promotion of a favourable and positive maritime environment will, therefore, require the creation of conditions wherein threats and challenges can be regularly monitored and appropriately countered. This would require adherence to international norms and laws by all actors, with strong maritime cooperation amongst all stakeholders, supported by requisite maritime force capability. The promotion of a favourable and positive maritime environment would also contribute significantly towards providing net security in the maritime area. The term net security describes the state of actual security available in an area, upon balancing prevailing threats, inherent risks and rising challenges in a maritime environment, against the ability to monitor, contain and counter all of these. 


\section{Conclusion}

Maritime security of IOR comprised of seaborne trade and infrastructure for its pursuit, management of sea resources, environmental issues and employment of naval forces, states international policies through maritime relationship is compendium of maritime strategically development . Increased activity throughout the Indian Ocean region due to expanding regional and global trade in goods, ideas, people, and resources has raised a new set of maritime security challenges. Historical state-based concerns such as geopolitical fragility, internal political upheaval, insurgency, inter-state tensions, sea-lane security, and territorial disputes are now coupled with growing threats from non-state sources and asymmetric risks. Among these are growing risks from nonstate actors including piracy, terrorism, and trafficking; the impacts of environmental degradation, resource depletion, climate change, and natural disasters; and weak states and failing institutions. These diverse challenges confront an equally diverse set of nations bordering this region. Such diversity in interests and capabilities saddles the region with political tensions and brings with it a greater danger of instability and conflict.

Maritime policy can be seen as the purview of coastal defence, so that the navy or coast guard would have the lead or sole role in determining policy. There are always compelling practical and political reasons to keep maritime decision making bodies separate. State's national security community sees the maritime space as an important dimension of its rising power status and a key component of its economic growth and energy security, although the strategic concepts of its maritime role have yet to be fully developed. Enhanced maritime capabilities will nonetheless have consequences for how its neighbors view India's role and ambition and its ability to contribute to regional peace and security.

The India continue to develop its force levels and capability for undertaking the range of missions and tasks, to provide overall maritime security and safeguard national maritime interests into the future. The efforts to develop all three elements of naval combat power, viz. conceptual, human and physical, would be progressed. The focus remain on developing and maintaining the Navy as a continually formidable, multi-dimensional, balanced and networked force, capable of countering the full range of maritime threats and challenges. Therefore, the maritime security strategy continued to be reviewed and refined, in relation to developments in the maritime strategic environment, so as to remain contemporary and relevant.

\section{Reference}

[1]. Aparupa Bhattacherjee (ed)The Maritime Great Game-India, China, US \& The Indian Ocean, Institute of Peace and Conflict studies, New Delhi, India (2015).p.211

[2]. David Michel \& Russell Sticklor, Indian Ocean Rising: Maritime Security and Policy Challenges. Govt.of India, New Delhi.(2014).p 144-48

[3]. Govt. of India, Indian Maritime Doctrine, 2009, Chapter 7, pp. 89-122.

[4]. Panikkar K.M, India and the Indian Ocean: An Essay on the Influence of Sea Power on Indian History, (1956).p. 19

[5]. Rupert Herbert-Burns, The Economic Times dated 27 March 2015.p.12

[6]. Caitlyn Antrim, International Law and Order: The Indian Ocean and South China Sea, (Oxford Press. New Delhi, 2015)pp145-148

[7]. Omprakash Dahiya, Maritime Security of India: Challenges and Opportunities, Employment News, New Delhi, (April 2015).p.18

[8]. Vijay Sakhuja, The Indian Ocean in 2015, IPCS Special Report, 167, January 2015.

[9]. Dhowan R. K, Ensuring Secure Seas: Indian Maritime Security Strategy, Indian Navy Naval Strategic Publication (NSP) (October 2015).p45

[10]. Ghosh P.K, Linking Indian and Chinese Maritime Initiatives: Towards a Symbiotic Existence, ORF issue brief, December, 2015.pp23-27

[11]. Gareth Price, India's Take on China's Silk Road: Ambivalence with Lurking Worries, Global Asia Vol10, No3 (2015) p-32

[12]. Russel, Daniel. Transatlantic Interests in Asia, U.S Department of State. Retrieved 3 August (2015).p125

[13]. Sen,R, Gupta and S.Y.S. Singbal(1988) Marine Pollution in the Indian Ocean - Problems, Prospects and Perspectives, Journal of the Indian Fisheries Association, (1988)pp..333-356.

[14]. Wyrtki, K. Physical Oceanography of the Indian Ocean In: The Biology of the Indian Ocean, editor B. Zeitzsch.el, Springer Verlag Berlin,(1973) pp. 18-36.

[15]. Johnston, R. Marine Pollution, Academic Press, London (1976), p.729.

[16]. Qasim, S.Z. and R. Sen Gupta, Some problems of coastal Pollution in India, Marine Pollution Bulletin (1988), p.100-106.

[17]. A Maritime Military Strategy for India (1989 - 2014), Indian Navy, 1988.pp.45-47 
[18]. Annual Report 2014 - 2015, Department of Animal Husbandry, Dairying and Fisheries, Ministry of Agriculture, Govt. of India.p.44

[19]. Annual Report 2014 - 2015, Earth System Science Organisation, Ministry of Earth Sciences, Govt. of India.p.16

[20]. Annual Report 2014 - 2015, Ministry of Defence, Govt. of India.p.22

[21]. Annual Report 2014 - 2015, Ministry of External Affairs, Govt. of India.p.23

[22]. Annual Report 2014 - 2015, Ministry of Shipping, Govt. of India.p.56

[23]. Annual Report 2014 - 2015, Oil and Natural Gas Corporation (ONGC).p.34

[24]. A Seaman's Guide to International Law (INBR 1650), Indian Navy, April 1999.p.105

[25]. Annual Report, Comprehensive Marine Fishing Policy - November 2004, Department of Animal Husbandry, Dairying and Fisheries, Ministry of Agriculture, Govt. of India, New Delhi, (2013)p.49

[26]. Cyber Doctrine, Flag Officer Doctrines and Concepts, Indian Navy, July (2013) p33

[27]. Central Statistics Office, Ministry of Statistics and Implementation Programme, Energy Statistics (2015).p.67

[28]. Govt. of India Foreign Cooperation Roadmap, Indian Navy Report (2014) p45

[29]. Handbook on the Law of Maritime Operations, Laws of Peacetime Naval Operations - INBR 1652, Vol I. P.234

[30]. Venkateswaran, S.V. On evaporation from the Indian Ocean, Indian Journal of Meteorology and Geophysics (1956) PP 265-284.

[31]. Hiranandani, The Handbook of International Humanitarian Law, Third Edition (ed), Dieter Fleck, (Oxford University Press, Oxford)2013,P.78

[32]. Dietrich, G. General Oceanography, Inter science, (New York, 1963) P.588.

[33]. United Nations Environmental Programme (UNEP) 1986 Draft .overview of the Coastal environmental problems of the South Asian Seas Region. (UNEP/WG. 153/3)

[34]. Jasjit Singh, India's Security in a Turbulent World (National Book Trust, New Delhi,2013) P-45

Author: Dr. Devakumar Jacob, Assistant Professor, School of Law Rights and Constitutional Governance. TISS, Mumbai. Mail-devakumar.jacob@tiss.edu 